\title{
MAROONED PLANTS: VERNACULAR NAMING PRACTICES IN THE MASCARENE ISLANDS
}

\author{
by CHRISTIAN A. KULL, EDWARD A. ALPERS, and JACQUES TASSIN
}

\begin{abstract}
This article explores possible histories of plant exchanges and plant naming tied to the slave trade between East Africa, Madagascar and the Mascarene Islands. The subsequent 'marronnage' of slaves on these islands - their escape from captivity, sometimes to live in mountain hideouts - continues to inspire cultural references. Inspired by the use of the adjective 'marron/marronne' for a number of plants on Reunion Island, we compile evidence of plant exchanges and plant naming from ecological records, historical accounts and the use of descriptive, emotive or symbolic vernacular names as clues for deepening our knowledge of historical societies and environments. The evidence from the Mascarenes opens a window into the role of the African diaspora in plant introduction, diffusion, domestication and cultivation. We document that maroons relied on a variety of wild, escaped and cultivated plants for their subsistence. We also highlight the role of marronnage in the popular and literary imaginary, with the result that many plants are named 'marron/marrone' in a metaphorical sense. Finally, we identify a few plants that may have been transported, cultivated, or encouraged in one way or another by maroons. Along the way, we reflect on the pitfalls and opportunities of such interdisciplinary work.
\end{abstract}

\section{CITATION}

Kull, CA, E Alpers \& J Tassin (2015) Marooned plants: vernacular naming practices in the Mascarene Islands. Environment and History 21 (1):43-75.

This is the authors archived version of the above paper published in Environment and History, Vol. 21, No. 1, special issue titled Transoceanic Exchanges (edited. by H. Rangan and J. Carney). The final definitive version is available through Environment and History (White Horse Press) via the following link:

http://dx.doi.org/10.3197/096734015X14183179969746

\section{INTRODUCTION}

What role did enslaved African and Malagasy people play in shaping the botanical landscapes of the Mascarene Islands? In descriptions of the botanical history of Mauritius and Réunion, the plant introduction efforts of high profile colonial botanists and administrators, like Bertrand-François Mahé de La
Bourdonnais and Pierre Poivre, attract most of the attention. In biological research, the focus is on plants cultivated by farmers, foresters, and gardeners, and how some escaped to become invasive environmental weeds. ${ }^{1}$

\footnotetext{
${ }^{1}$ Richard Grove, Green Imperialism
} 
Yet for a long part of these islands' history, the largest portion of the human population was enslaved, which begs the question of enslaved peoples' possible contribution to the introduction, diffusion and cultivation, but also naming, of the plants shaping today's Mascarene environments.

The phenomenon of marronnage by enslaved Africans and Malagasy - their escape from captivity, sometimes to live in mountain hideouts - attracts our particular attention, for here the maroons regain more agency and independence. Furthermore, popular language in the Mascarenes seems to associate the maroons with a number of plants: at least 114 common names of plants include the adjective marron/marronne. ${ }^{2}$ In this article we undertake an initial investigation into one aspect of the nomenclature history of plant exchanges. In particular, we seek to understand how these plants acquired the designation marron by examining evidence of plant exchanges from the ecological record, historical accounts and oral traditions. Our focus here is on the history of the slave trade between East Africa, Madagascar and the Mascarene islands (Figure 1) and, in particular, of marronnage.

For the most part, the histories of plant exchanges across the Indian Ocean have focused on much earlier periods. The movement of food crops between Africa

(Cambridge: Cambridge University Press, 1995); Jacques Tassin, Julien Triolo, Vincent Blanfort and Christophe Lavergne, 'L'évolution récente des stratégies de gestion des invasions végétales à l'île de la Réunion." Revue d'Écologie (Terre et Vie) 64 (2009): 101-15.

${ }^{2}$ Source: database of the Conservatoire Botanique National de Mascarin (http://flore.cbnm.org/ accessed 19 May 2012). and Asia dates as far back as the third millennium BCE and involves a variety of basic staples such as sorghum (Sorghum bicolor), pearl millet (Pennisetum glaucum) and finger millet (Eleusine coracana), numerous varieties of cowpea (Vigna unguiculata) and hyacinth bean (Lablab purpureus) from Africa to South and South-east Asia; and banana (Musa x paradisiaca), water yam (Dioscorea alata), taro or cocoyam (Colocasia esculenta), coconut (Cocos nucifera) and common or broomcorn millet (Panicum miliaceum) to Africa and Madagascar. The sources for tracing the histories of these important exchanges are archaeology, ethnobotany, genetics and historical linguistics. ${ }^{3}$ Complementary to these studies of the broad movement of plants and animals across the Indian Ocean are sub-regional studies that focus on more restricted maritime regions of the Indian Ocean during antiquity. ${ }^{4}$ By contrast, the slave

\footnotetext{
${ }^{3}$ See, for example, Dorian Q. Fuller and Nicole Boivin, 'Crops, Cattle and Commensals across the Indian Ocean: Current and Potential Archaeobiological Evidence', Études Océan Indien 42-43 (2009): 13-46; Dorian Q. Fuller, Nicole Boivin, Tom Hoogervorst and Robin Allaby, 'Across the Indian Ocean: the prehistoric movement of plants and animals', Antiquity $\mathbf{8 5}$ (2011): 544-558; Haripriya Rangan, Judith Carney and Tim Denham, 'Environmental History of Botanical Exchanges in the Indian Ocean World', Environment and History 18 (2012): 311-342; Katherine Neumann and Elisabeth Hildebrand, 'Early Bananas in Africa: The state of the art', Ethnobotany Research \& Applications 7 (2009): 353-362.

${ }^{4}$ Timothy Denham, 'From domestication histories to regional prehistory: Using plants to re-evaluate Early and Mid-Holocene interaction between New Guinea and Southeast Asia', Food \& History 8 (2010): 3-22; Martin T. Walsh, 'Island subsistence: hunting, trapping and the translocation of wildlife in the Western Indian Ocean', Azania: Archaeological Research in Africa 42 (2007): 83-113. We should note that
} 
trade from East Africa and Madagascar to the Mascarenes dates only to the seventeenth century, while the slave trade from Mozambique to Madagascar emerged in the nineteenth century. ${ }^{5}$

Human intentionality is an important element in these histories, although it is clear that not all plant or animal translocations were actually intended. Nevertheless, the general assumption appears to be that the humans involved were pioneering settlers. ${ }^{6}$ Enslaved persons do not appear as a category of analysis in any of these studies of plant exchanges. We know, however, that captive African and Malagasy people carried important elements of their cultures in their forced migration from East Africa and Madagascar to the islands of the south-west Indian Ocean, and that marronnage has deeply

Walsh extends his analysis into the twentieth century.

${ }^{5}$ If we include the Comoro Islands in the region, however, the population links to East Africa and Madagascar date as far back as the last centuries of the first millennium CE. See Philippe Beaujard, 'East Africa, the Comoros Islands and Madagascar before the sixteenth century: on a neglected part of the world system', Azania $\mathbf{4 2}$ (2007): 15-35.

${ }^{6}$ For example, none of the exemplary studies by Madeleine Ly-Tio-Fane mention anything at all about non-European contributions to plant introductions at Mauritius. See Madeleine LyTio-Fane (ed.) Mauritius and the Spice Trade, the Odyssey of Pierre Poivre (Port Louis: Esclapon, 1958); Ly-Tio-Fane, The Triumph of Jean Nicolas Céré and his Isle Bourbon collaborators (Paris \& The Hague: Mouton, 1970); Ly-Tio-Fane, Le Géographe et le Naturaliste à l'Île-de-France: ultime escale du Capitaine Baudin (Port-Louis: MSM Ltd., 2003); Ly-Tio-Fane, La Société Royale des Arts et des Sciences de l'île Maurice, 1829-2004: notice historique (République de Maurice: Société Royale des Arts et des Sciences de l'Île Maurice, 2004). penetrated the local imaginary and culture. Language, music and dance were refashioned in diaspora. ${ }^{7}$ In order to approach the possibility that enslaved or marooned Afro-Malagasy may also have introduced or utilised certain plants in the Mascarenes we need first to say something about the history of the slave trade to these closely connected islands.

\footnotetext{
${ }^{7}$ Pier M. Larson, Ocean of Letters: Language and Creolization in an Indian Ocean Diaspora (Cambridge: Cambridge University Press, 2009); Edward A. Alpers, 'When Diasporas Meet: The musical legacies of slavery and indentured labor in the Mascarene Islands', in Chouki El Hamel and Timothy Cleaveland (eds) Confluence of Cultures and Convergence of Diasporas (Trenton: Africa World Press, forthcoming).
} 
Figure 1. The South-west Indian Ocean. Map: E. Alpers.

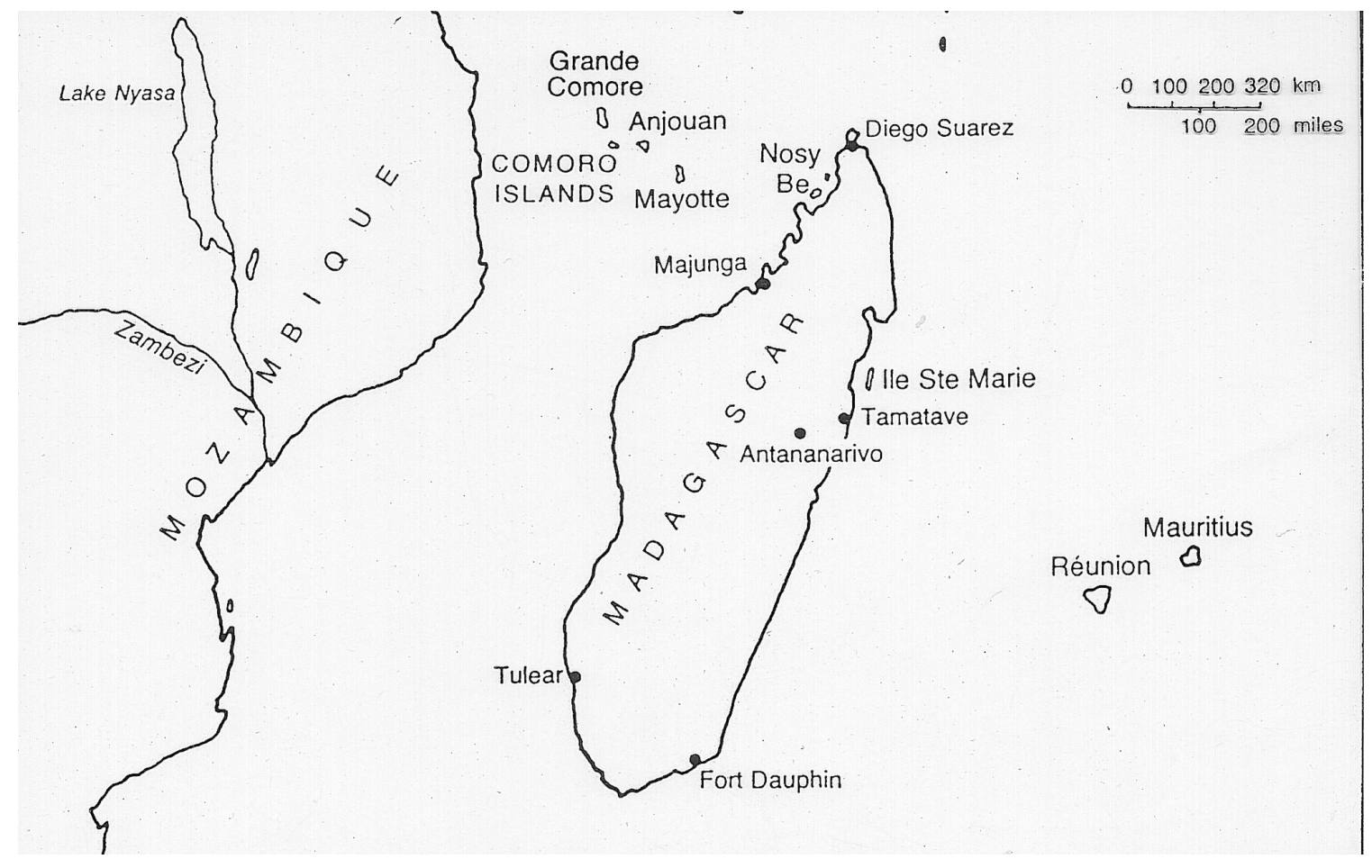

\section{HISTORY OF SLAVERY IN THE MASCARENES}

The Mascarenes remained unpopulated until first the Dutch and, more effectively, the French colonised the islands in the early modern period. Although the Mascarenes were probably known to medieval Arab sailors and geographers, there is no evidence that they were ever settled before the seventeenth century. ${ }^{8}$ Nor did the Portuguese, who had a policy of minimum landfall on the route to India, seek to settle them in the sixteenth century. The Dutch established a presence at Mauritius in 1638, hoping

\footnotetext{
${ }^{8}$ Shawkat M. Toorawa, 'Wāq al- wāq: Fabulous, Fabular Indian Ocean (?) Islands', Emergences 10/2 (2000): 387-402.
}

that it would become a way-station on the route to their colony in Batavia, but once they settled Cape Town in 1652 they lost interest in Mauritius, which they finally abandoned altogether in 1710. ${ }^{9}$ The sporadic Dutch occupation certainly had an impact on the ecology of the island, cutting down large sections of forest for the ebony trees, collecting ambergris, introducing rats and eliminating the hapless Dodo. Except for a few runaway enslaved Malagasy who apparently died out, the island was again unpopulated until French settlers and their slaves from their colony on the island of Bourbon

\footnotetext{
${ }^{9}$ P.J. Moree, A Concise History of Dutch Mauritius, 1598-1710 (London/New York: Kegan Paul; Leiden: International Institute for Asian Studies, 1998).
} 
(modern Réunion) arrived in 1721. The French had begun to colonise Bourbon as early as 1663 , bringing male and female slaves and undertaking frequent trips to Madagascar.

Yet French claims to the islands languished until the transformations that ultimately led to the creation of viable plantation economies on both islands. This dramatic reorganisation of the Mascarenes was masterminded by $\mathrm{La}$ Bourdonnais, who governed the French islands from 1735 to 1746 . Various commercial crops were tried, among them coffee and indigo, but in the end it was sugar that really transformed the islands' economies and societies, becoming a mainstay of the economy in the early nineteenth century. The plantation cultivation of sugar, in particular, drove the slave trade from Madagascar and Mozambique to the Mascarenes.

Richard Allen suggests that the volume of the slave trade to the Mascarenes between 1670 and 1848 totalled perhaps as many as 388,000 souls, with captive Malagasy comprising more than half of the forced migrants in the eighteenth century and so-called Mozambiques dominating the slave trade after $1800 .^{10}$ Part of the business of creating a workable slave economy was feeding the labour force. It was to that end, therefore, that La Bourdonnais

\footnotetext{
${ }^{10}$ Richard B. Allen, 'The Mascarene slave-trade and labour migration in the Indian Ocean during the eighteenth and nineteenth centuries', in Gwyn Campbell (ed.) The Structure of Slavery in Indian Ocean Africa and Asia (London and New York: Routledge, 2003) pp. 33-50. See also Allen, 'The Constant Demand of the French: The Mascarene Slave Trade and the Worlds of the Indian Ocean and Atlantic during the Eighteenth and Nineteenth Centuries', The Journal of African History 49 (2008): 43-72.
}

introduced manioc (cassava, Manihot esculenta) in 1736, having carried the plant from Brazil. To overcome settler resistance to planting the American crop, he required colonists 'to plant 500 feet of manioc for each head of slave'. ${ }^{11}$ The role of this tuber in feeding a large, settled subaltern population cannot be overemphasised. Indeed, the importance of manioc as a staple for African labourers at Réunion was noted as late as 1888 , when the Protector of Immigrants recommended this food as a supplement to the diet of so-called 'free labour emigrants' from Inhambane, Mozambique. ${ }^{12}$

\section{PETIT AND GRAND MARRONNAGE ON MAURITIUS AND RÉUNION}

Marooning was rife on both of the Mascarene Islands during the era of

\footnotetext{
${ }^{11}$ Mémoire pour le sieur de La Bourdonnais, avec les pièces justificatives (Paris: Delaguette, 1750) p. 11. Compare the clear evidence for the introduction of manioc to the Mascarenes with the debate over its introduction to Madagascar. There Raymond Kent argued for an early introduction through the agency of Africans arriving on the west coast of the great island, whereas Jean-Pierre Raison suggests instead that the introduction of manioc dates only to the later eighteenth century. Raison's chronology seems verified by Gwyn Campbell's note that cultivation of manioc was encouraged during the reign of the powerful Malagasy ruler Andrianampoinimerina (1787-1810). See Raymond Kent 'Note sur l'introduction et la propagation du manioc à Madagascar', Terre Malgache 5 (1969): 177-183; Jean-Pierre Raison 'L'introduction du manioc a Madagascar: un problème non résolu', Terre Malgache $\mathbf{1 3}$ (1972): 223-8; Gwyn Campbell, David Griffiths and the Missionary 'History of Madagascar' (Leiden and Boston: Brill, 2012) pp. 523-4, n.2.21.

${ }^{12}$ Archives Nationales d'Outre-Mer, Aix-enProvence, France, Réunion 350/2465, SaintDenis, 29 July 1888.
} 
legal slavery, up until slavery was abolished - on Mauritius in 1835 and on Réunion in 1848. To characterise the act of marronnage, it is useful to distinguish between short-term desertions, or petit marronnage, and long-term escapes to remote corners of the islands, or grand marronnage. On Mauritius, 45 per cent of the slave population annually fled captivity, a figure that rose to eleven to thirteen per cent in the third decade of the nineteenth century. Most desertions lasted less than a month, qualifying as petit marronnage in official French records; most also involved only a single individual, although small groups of maroons were not unusual, especially in the eighteenth century. ${ }^{13}$ Most maroons were men, constituting some eighty per cent of all fugitives in Mauritius. ${ }^{14}$ Allen argues that, over time, marooning became a way to exercise a limited amount of freedom within the context of a system of bonded labour. Visiting friends and relatives was one feature of this form of marronnage. It bears noting here that in such circumstances gaining

\footnotetext{
${ }^{13}$ Allen, 'A Serious and Alarming Daily Evil: Marronage and Its Legacy in Mauritius and the Colonial Plantation World', in Edward Alpers, Gwyn Campbell and Michael Salman (eds) Slavery and Resistance in Africa and Asia (London and New York: Routledge, 2005) pp. 20-36, cited at p. 24.

14 Allen, Slaves, Freedmen, and Indentured Labourers in Colonial Mauritius (Cambridge: Cambridge University Press, 1999) p. 42. From the late eighteenth century until the late 1820 s the gender ratio of slaves on Mauritius was roughly $2: 1$, men to women, declining to about $1.5: 1$ in the last few years before abolition in 1835. Source: Correspondence from Richard Allen to Ned Alpers 31 July 2014, on 'Mauritian Slave Population, 1735-1832'. Allen's estimates are based on R.R. Kuczynski, Demographic Survey of the British Empire, vol. 2 (London: Oxford University Press, 1949). Our thanks to Professor Allen for sharing these data.
}

access to food supplies may not have been a major problem for maroons. Theft was one option available, but so was hospitality from friends and relatives who received visits from these short-term fugitives. Describing the presence of maroons in Grande Rivière, Mauritius, soon after emancipation, British Quaker missionary James Backhouse noted, 'These people live on the wild produce of the country, or by depredation on the crops and herds of the colonists'. ${ }^{15}$ Three decades later American traveller Nicolas Pike reported that 'our guide told us this forest was formerly infested by maroon slaves, who committed great depredations on the surrounding plantations, driving off cattle, [and] robbing the poultry-yards'. ${ }^{16}$ Only in the case of grand marronnage, however, where fugitives took refuge in the more isolated, forested regions of the island would foraging have needed to become more intensive and the possibility of drawing on knowledge of available flora a more valuable resource for survival. Although there is one isolated account of a maroon community at Le Morne Brabant in about $1769-70,{ }^{17}$ except for accounts of the fear these small bands of maroons generated among French plantation owners and officials, and of the capture of the most notorious among

\footnotetext{
${ }^{15}$ James Backhouse, A Narrative of a Visit to the Mauritius and South Africa (London: Hamilton, Adams and Co., 1844) p. 6.

${ }^{16}$ Nicolas Pike, Sub-Tropical Rambles in the Land of the Aphanarpteryx. Personal Experiences, Adventures, and Wanderings in and around the island of Mauritius (New York: Harper \& Brothers, 1873) p. 243.

${ }^{17}$ Maxmilien Wiklinsky quoted in Amédée Nagapen, Le Marronage à l'Isle de France-Ile Maurice: Rêve ou Riposte de l'Esclave? (PortLouis: Centre Culturel Africaine, 1999) p. 144.
} 
them, we know almost nothing of the lives of these longer-term maroons on Mauritius. According to Satyendra Peerthum, who has searched the Mauritian National Archives carefully for sources on maroon communities in rural Mauritius, in the early nineteenth century 'there was an extremely limited amount of food available for their survival. The process of gathering food proved to be an arduous, daily struggle for all the Mauritius maroons who either lived in maroon gangs or bands or by themselves.' Among the foods they could sometimes access he states that 'they ate mostly tenracs or tangs, couroupas or snails, manioc, patates, du miel or honey, songe, mahis or maize, and the roots of various unidentified plants'. ${ }^{18}$ Travelling in the interior of the island in the first decade of the nineteenth century, Jacques Gérard Milbert came across some goat bones that he assumed to have been left by either maroons or hunters, as well as 'debris of monkeys [that] had served as food for a few maroon blacks'. ${ }^{19}$

Archaeological investigation at Le Morne revealed animal bones, but - not surprisingly - no plant remains. ${ }^{20}$

\footnotetext{
${ }^{18}$ Satyendra Peerthum, 'Maroon Diet during the Early Nineteenth Century', in Vijayalakshmi Teelock (ed.) Maroonage and the Maroon Heritage in Mauritius (Réduit, Mauritius: University of Mauritius, 2005) Appendix III, pp. 176-8, quoted at p. 176.

${ }^{19}$ Jacques Gérard Milbert, Voyage pittoresque à l'Ile-de-France, au cap de Bonne-Espérance et à l'île de Ténériffe (Paris: A. Nepveu, 1812) vol. 2, pp. 75-6.

${ }^{20}$ Vijaya Teelock, 'Archaeology and History of Le Morne Brabant', in Teelock (ed.) Maroonage and the Maroon Heritage, pp. 153-5; Amitava Chowdhury, 'The symbolic and archaeological significance of Le Morne Brabant: a fugitive slave site of Mauritius', Journal of Indian Ocean Archaeology 3 (2006): 50-61.
}

It is, therefore, more to Réunion that we look for clues to possible links between plants bearing the designation marron/marronne and the historical phenomenon of flight from slavery, for the island hosted a stronger tradition of grand marronnage. Although they are sister islands, Réunion is much younger geologically than Mauritius.

Accordingly, while Mauritius presents an older volcanic landscape, with its heights less dramatic and its plains more generous, Réunion is marked by three prominent mountainous zones formed by shield volcanoes clustered together in the west-central region of the island that reach heights exceeding 3,000 metres; to the south-east it is still home to an active volcano, the Piton de la Fournaise. With their thick forests and deep ravines, the three mountainous 'cirques' constitute ideal territory for fugitives and today are a major tourist attraction for adventurous hikers. To a large extent they also remain home to poor isolated villages that stand largely outside mainstream Réunion. 
Figure 2. Topographical Map of La Réunion. Source: Google Maps.

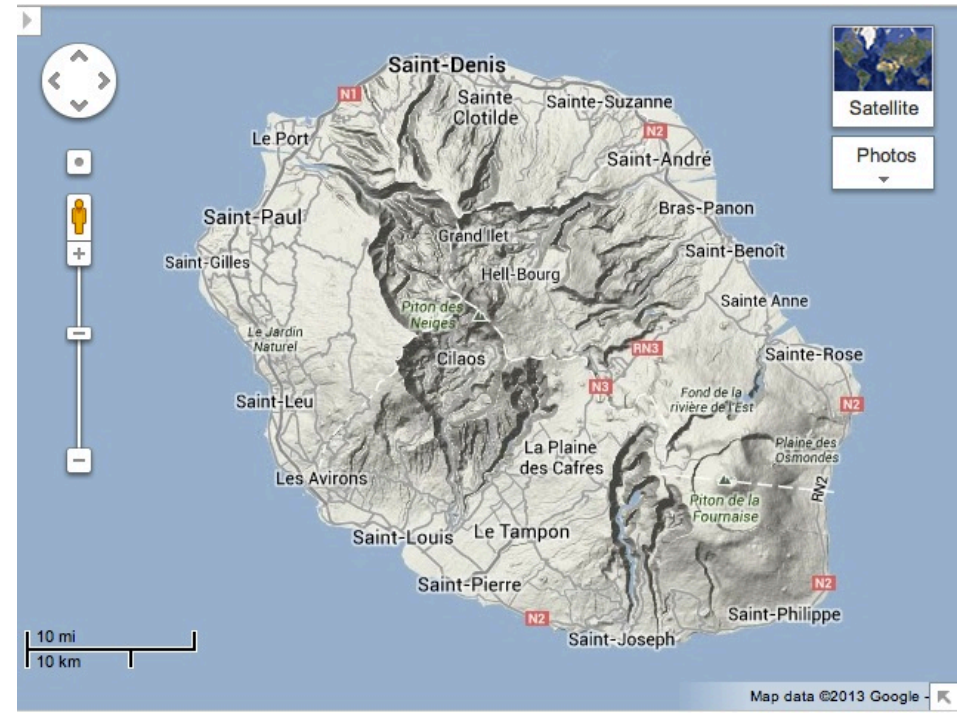

Figure 3. Topographical Map of Mauritius. Source: Google Maps.

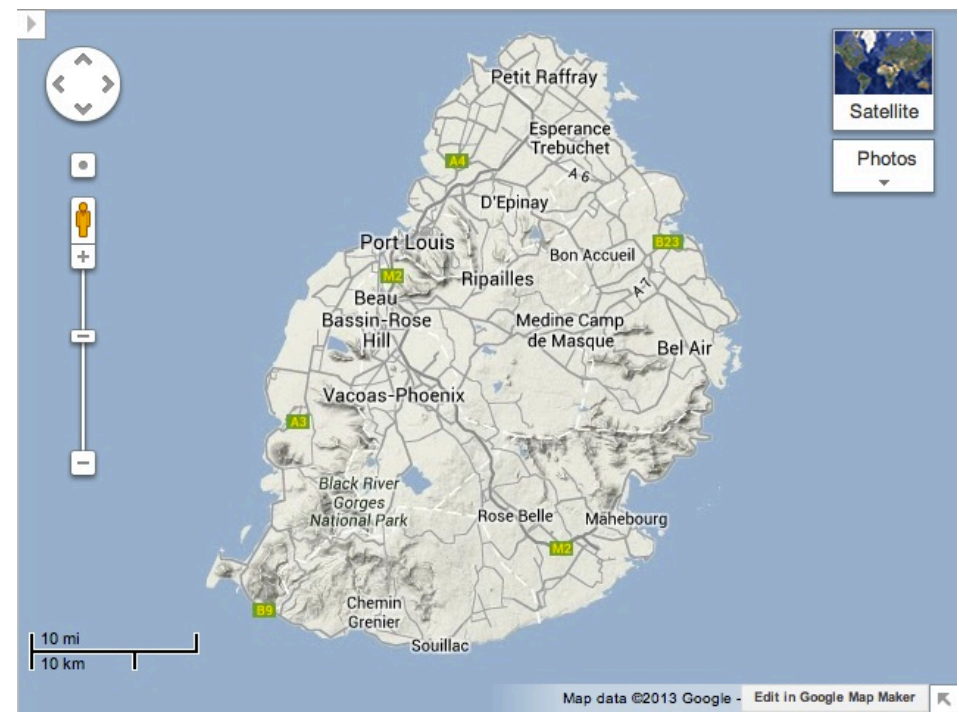

Considering the different landscapes of the two islands, it is not surprising that, whereas flight in Mauritius was characterised by short-term runaways or petit marronnage, in Réunion it was grand marronnage that dominated. Feared for their raids, called 'descentes', ${ }^{21}$ down from their mountain fastnesses, some ninety per cent of

\footnotetext{
${ }^{21}$ Jean Barassin, 'La révolte des esclaves à l'île Bourbon (Réunion) au XVIII' siècle', in Mouvement de Populations dans l'Océan Indien (Paris: Librarie Honoré Champion, 1979) p. 366;
} 
grands marrons from the fetters of Bourbon slave society were Malagasy. ${ }^{22}$ They lived in camps that numbered from a dozen or more individuals living in temporary shelters to as many as seventy individuals inhabiting huts constructed of wood. ${ }^{23}$ In addition to secreting their encampments high up in the mountains and deep in the ravines, as well as retreating to caves when pursued by the relentless slave patrols, men were always armed. ${ }^{24}$ Maroon society in Réunion was hierarchical, each camp led by its own chief, while the different chiefs maintained a loose political network and observed a certain degree of hierarchy among themselves. The notoriety of the most important of these maroon 'kings' as they were known is embodied in the names of the very mountains that they inhabited in the eighteenth century: In the mountainous caldera known as Cirque de Salazie, a name possibly Malagasy in origin meaning 'good encampment', there is the Piton d'Enchaing, called after a famous maroon leader Anchaing; also Mafate, the name of a famed Malagasy sorcerer; and the peak within the massif of Piton des Neiges named after the

Prosper Ève, 'Les formes de résistance à Bourbon de 1750 à 1789', in Marcel Dorigny (ed.) Les Abolitions de l'Esclavage de L.F. Sonthonax à V. Schoelcher 179317941848 (Paris: Presses Universitaires de Vincennes and Éditions UNESCO, 1995) p. 57.

${ }^{22}$ Barrasin, 'La révolte des esclaves', pp. 358, 360 .

${ }^{23}$ For a map of where these camps were located in the eighteenth century, see Jean-Marie Desport, De la servitude à la liberté: Bourbon des origines à 1848, second ed. (Réunion: C.C.E.E/Océan Editions, 1989) p. 68.

${ }^{24}$ Barassin, 'La révolte des esclaves,' pp. 361-4, 368-9; Ève, 'Les formes de résistance à Bourbon,’ pp. 52, 58. legendary maroon 'king' Cimendef, who is said to have taken his name from the Malagasy tsy andevo, 'not a slave'. In addition, the mountainous region of Cilaos takes its name from Malagasy $t s y$ laosana or tsy ilaozana, 'a place of no return' or 'the place one never leaves'. It should be noted, however, that even on Mauritius there are several places known by the toponym 'Maroon'. 25

\section{MAROONS AND FOOD PLANTS: THE HISTORICAL AND LITERARY RECORD}

The Maroon 'kings' of Réunion inspired an important literature that both romanticised and demonised grand marronnage on the island. ${ }^{26}$ Buried in this literature from the first half of the 1840 s, are several accounts of how maroons on Réunion fed themselves. According to French abolitionist Victor Schoelcher, 'the first action of whites who tracked down a retreat of the blacks is to burn the huts, cut down the banana trees, and lay waste to the fields of manioc and sweet potatoes that they found'. ${ }^{27}$ The first novel by a Réunionnais writer was published in 1844 by abolitionist Louis Timagène Houat. The novel concerns a group of four runaways, three Malagasy and a Creole, who are being chased into the Cirque de Salazie by a band of maroon catchers. Although they are caught and

${ }^{25}$ Amédée Nagapen, 'Le Toponyme Marron', in Teelock (ed.) Maroonage and the Maroon Heritage, pp. 159-64.

${ }^{26}$ Edward Alpers, 'The idea of Marronage: Reflections on Literature and Politics in Réunion', in Alpers, Campbell and Salman (eds) Slavery and Resistance, pp. 37-48.

${ }^{27}$ Victor Schoelcher, Des colonies françaises: abolition immédiate de l'esclavage (Paris: Pagnerre, 1842) p. 109. 
two of them killed, the other two escape with help from a heroic maroon named Frême, who teaches them how to survive as maroons in the mountains. One source of food Houat describes are the many fruit trees that one encounters in the highlands, such as 'date trees, guava trees, banana trees, [and] vavanguier trees'; elsewhere he mentions a meal of 'grilled bananas, sweet potatoes, and a salad of palm cabbages'. He notes further the preparation of 'vegetal plants that they eat raw' and tells his reader how Frême taught his acolytes how to use a bow and a sling to take birds and wild animals for food, and how to find sources of water, honey, fruits, plants, and roots, 'all things necessary' ${ }^{28}$ Contemporaneous French traveller and linguist Théodore Pavie confirmed the array of foodstuffs available to maroons in his vivid tale of a maroon and a French maroon-chasing squad. 'The palm tree, which grows abundantly in these heights offers them easy nourishment; there are also planted banana trees and some roots'. Echoing Houat, he describes finding the ashes of a recent maroon meal where they had cooked 'bananas and sweet potatoes, some stems of stripped palm fronds'. ${ }^{29}$

There are no indications in these sources that any of these foods had been introduced to Réunion by enslaved Malagasy. As we have already observed, manioc was introduced by La

Bourdonnais as a slave food. Among the other food sources included in the

\footnotetext{
${ }^{28}$ Louis Timagène Houat, Les Marrons (Paris: Ebrard, 1844) pp. 49, 59, 96, 104.

29 Théodore Pavie, 'Une chasse aux nègresmarrons', Revue des Deux Mondes 10 (1845): 14-15, 21. It would be interesting to see if Houat and Pavie shared the same source for their accounts of this maroon meal.
}

accounts of these nineteenth-century authors, all were either introduced at the time of colonisation or native to Réunion. The date palm (Phoenix dactylifera) was apparently present on the island from 1668. Although the source of its introduction is unknown, it was reintroduced by the famous horticulturalist Pierre Poivre when he was Intendant at the Mascarenes (176772). ${ }^{30}$

As far as the guava, one species, Psidium guajava, known locally as Goyavier, Goyavier blanc, or Goyavier pomme, is native to the Americas. ${ }^{31} \mathrm{~A}$ second kind of guava tree, called Goyavier fraise (Psidium cattleyanum) was introduced either as early as 1712 or as late as 1818 , depending on the source. ${ }^{32}$ Both flourished and became naturalised on the island; both produced edible fruits. Exactly which guava tree was recorded by Houat remains uncertain, but the confusion regarding the date of the introduction of Psidium cattleyanum highlights the problem of sources that this kind of research encounters and the need for more careful historical research in the field and archives. Yet we suspect, based on the

\footnotetext{
30 'Palmier dattier. Fruit: La Datte. Phoenix dactylifera', www.mi-aime-aou.com/palmier_dattier.php (accessed $25 \mathrm{Jul}$. 2013), although this source misdates Poivre's introduction of the date palm to 'the end of the $18^{\text {th }}$ century'.

${ }^{31}$ www.mi-aime-a-ou.com/goyavier blanc.php (accessed 25 Jul. 2013); Jacques Tassin, Arbres et arbustes introduits dans les îles tropicales (Chevagny sur Guye: Editions Orphie) p. 225.

32 'Goyavier (Psidium cattleianum)' in Robert Chaudenson (ed.) Encyclopédie de La Réunion, vol. 8: 'La Faune et la Flore' (Saint-Denis: Livres Réunion, 1980) pp. 32-3; www.mi-aimea-ou.com/goyavier goyave.php (accessed $25 \mathrm{Jul}$. 2013).
} 
habitat preferences and ecological characteristics of the two guavas, that the plant mentioned by Houat was more likely Psidium guajava. We also note that there is a plant known in the vernacular as Goyave marron or Change écorce (Aphloia theiformis) that is indigenous to Africa and the islands of the south-west Indian Ocean. It does not, however, produce edible fruit; rather, 'it is traditionally used at Réunion to treat fevers, pains, malaria, inflammations and as a purgative' ${ }^{33}$ The name Goyave marron comes from the similarity of its bark with that of Psidium guajava.

As for the 'banana tree' (Musa spp., which is not botanically a tree), it seems to have already been present on Réunion at the time of French occupation, although how it was carried to the island remains unclear. The name for the plant on the island was not initially 'banana' but 'fig', a usage that reflects the late introduction of the word 'banana' in the French language and which persists in creole. 'At Réunion the term employed in the eighteenth and nineteenth centuries was undoubtedly 'figue' and banana was only really popularised more recently, ${ }^{34}$ Carry baba-figue, which is a curry cooked using a banana flower, is one of the most famous traditional dishes of Réunion. To the extent that this claim may be generally correct, how is one to explain all three writers' usage of 'banana' in the midnineteenth century descriptions of maroon food sources?

Last among the trees mentioned by Houat is the vavanguier or Vavangue

\footnotetext{
${ }^{33}$ www.mi-aime-a-

ou.com/Aphloia theiformis.php (accessed $25 \mathrm{Jul}$. 2013).

34 'Le nom créole de la banane', in Chaudenson (ed.) Encyclopédie de La Réunion, vol. 8, p. 21.
}

(Vangueria madagascariensis), also called locally Tamarin des Indes, a native of Madagascar. ${ }^{35}$ The name is likely from the Malagasy language. ${ }^{36}$ The ripe fruits of this plant turn reddishbrown when ripe and are said to taste like a compote of sour apple. Testimony to how thoroughly this small tree has become indigenised in Réunion is the folk saying 'aller aux vavangues' which translates as 'to play truant/hooky' and derives from the custom of children on the way to school 'passing through the ravine and filling their pockets with these wild and providential fruits' ${ }^{37} \mathrm{~A}$ similar proverb is 'filer dans les vavangues', which means not being able to lay one's hands on something for which one is searching. Its alleged origin dates to the early sixteenth century when, in about 1513, a Portuguese ship's captain and eventual Viceroy of India Pero Mascarenhas 'discovered' the Mascerene islands. Legend has it that when he arrived at Réunion 'the island was covered with vavanguiers' and formed an 'almost impenetrable copse' in which it was easy to hide. When Mascarenhas sent his men to fetch water at what is now Saint-Paul, on the north-west of the

${ }^{35}$ www.mi-aime-a-ou.com/vavangue.php (accessed 25 Jul. 2013).

${ }^{36}$ Robert Chaudenson, Le Lexique du Parler Créole de la Réunion (Paris: H. Champion, 1974) p. 530.

37 'Le vavanguier', Conservatoire Botanique National de Mascarin, http://www.cbnm.org/domainejardins/lescollections/6-collection-verger/66-le-vavanguier (accessed 22 Jul. 2013). A different species of vavanguier (Vangueria infausta) is widespread in South Africa, where its ripe fruit is described as a combination of tamarind and apple compote. Although it is usually eaten fresh, in South Africa it is also dried to use in periods of food shortage: en.termwiki.com/FR:wild medlar. 
island (see Map 2), they stayed hidden from him so thoroughly that he complained, 'These rascals carry on in the vavangues when one calls them'. ${ }^{38}$ What is most interesting about this plant is the way in which it has become incorporated into réunionnais popular culture. This is surely one direction that future research might take in exploring the histories of naming practices on the island.

Aside from the trees, each author names 'sweet potatoes' as a food eaten by maroons. Given common confusion with yams, we cannot know for sure whether this tuber was the African yam

(Dioscorea spp.) or the South American sweet potato (Ipomoea batatas), but we can assert that the former was well known in both East Africa and Madagascar and was traditionally part of Réunion creole cuisine, and the latter was disseminated globally in the sixteenth century and introduced to Réunion from the earliest times of colonisation by the French. Among the sweet potatoes, confusingly, there is a variety known as 'African'. 39 Two creole names for yams, cambarre and hoffe, have Malagasy dialectal origins (kambara, ovy), suggesting Malagasy agency in their introduction or propagation. $^{40}$

Neither Houat's palm cabbage (choux palmistes) nor Pavie's stripped palm fronds (tiges de palmistes effeuillées) give any indication of what species of

\footnotetext{
${ }^{38}$ Gilles François Crestien, Causeries historiques (Réunion: Challamel ainé, 1881) p. 18 , also available at www.mi-aime-aou.com/filer_dans_les_vavangues.php.

${ }^{39}$ www.mi-aime-a-ou.com/patate_douce.php; www.mi-aime-a-ou.com/igname cambarre.php (accessed 28 Jul. 2014).

${ }^{40}$ Chaudenson, Lexique, pp. 500 and 517.
}

palm was the source. It is likely that they were either the native palm Dictyosperma album or Acanthophoenix rubra, which have both become rare following excessive collection. French traveller Jean-Baptiste Bory de SaintVincent, who visited the island in the first years of the nineteenth century, recounted the proper method for preparing chou palmiste while noting that 'this method is used by hunters and by maroons (les noirs-marrons)' ${ }^{41}$

A number of other plant species were likely relied on by maroons, particularly those that were and still are similarly used in Africa or Madagascar. For instance, Annona squamosas (sugarapple) has become naturalised on the west coast of Réunion and is still very appreciated by creoles. Likewise, Colocasia esculenta (taro), which is also naturalised and is easy to cultivate, could have been grown in the mountain cirques of the central part of the island during grand marronnage. It came from Asia to Africa several thousand years ago, and is known as jimbi or myugwa in Swahili, and saonjo in Malagasy, a name which has persisted in creole as songe. ${ }^{42}$ Prosper Eve notes that on Bourbon maroon bands cultivated 'maize, manioc, taro, sweet potatoes,

\footnotetext{
41 Quoted in Chaudenson (ed.) Encyclopédie de La Réunion, vol. 8, p. 42. It is unfortunate that C. Gaudichaud lost his botanical collections from both Mauritius and Réunion, for which see Louis Claude Desaulses de Freycinet, Voyage autour du monde : entreprises par ordre du roi ... exécuté sur les corvettes de S.M. l'Uranie et la Physicienne, pendant les années 1817, 181, 1819 et 1820 ... (Paris: Chez Pillet Ainé, 18241844), Section 3, 'Botanique', by C. Gaudichaud, pp. 18, 31-2.

${ }^{42}$ Fuller et al., 'Across the Indian Ocean'. Chaudenson, Lexique, p. 522.
} 
[and] potatoes' ${ }^{43}$ Similarly, in the early nineteenth century on Mauritius, Milbert identified sonzes as Arum esculentum (a synonym of Colocasia esculenta) and noted both that they grew naturally by streams and that 'the blacks eat their roots either by whim or by need; but it is particularly food for pigs'. ${ }^{44}$ The fruit of Pandanus utilis, which is native to Réunion and grows near the sea, is edible if cooked. The creole language uses a Malagasy name for this genus vakoi (for vakona) - suggesting that Malagasy people familiar with other species of this plant back home sought to use it. The Stachytarpheta genus includes several herbaceous plant species that are edible and might have been used as spinach. At the beginning of the nineteenth century, French naval surgeon Grégoire Avine remarked upon 'a great consumption of brettes, a kind of spinach that provides an ample and healthy food for the creoles, who do not dine well unless they have a platter of brettes on their table'. ${ }^{45}$ Milbert indicates that there were several varieties called brèdes, a word indicating any variety of greens, including 'brède malgache, which one eats like spinach'. ${ }^{46}$ According to Auguste Billiard, who visited Réunion in 1820 and visited several abandoned maroon camps in the mountains, "they feed themselves on wild brèdes, hearts

\footnotetext{
${ }^{43}$ Ève, Les esclaves de Bourbon, la mer et la montagne (Paris: Karthala \& Saint-Denis: Université de La Réunion, 2003), p. 101.

${ }^{44}$ Milbert, Voyage pittoresque, vol. 1, pp. 107, 128.

${ }^{45}$ Raymond Decary, Les Voyages du Chirugien Avine à l'île de France et dans la mer des Indes au début du XIX $X^{e}$ siècle, Mauritius Archives Publication No. 5 (Paris: G. Durassié, 1961) p. 17.

${ }^{46}$ Ibid., p. 109.
}

of palm (choux palmistes), or potatoes which, once brought, then reproduced spontaneously among the rocks'. ${ }^{47}$ Two decades later on Mauritius, Backhouse 'was surprised to see a variety of vegetables, cooked and eaten under the name of Bredes, or Brettes', even providing the names of several different plants known popularly by this generic name. ${ }^{48}$ As yet another example, Typhonodorum lindleyanum ('via' in both creole and Malagasy) is also naturalised near Saint-Gilles; it is used in Madagascar as its seeds and tubers are edible, though seeds have to be boiled, and tubers are only used during starvation periods. Malagasy maroons certainly knew how to use this plant. None of the vernacular names of these plants involve the term marron(ne), but several were known in creole by their Malagasy names, suggesting that their use by slaves and maroons was central to their introduction, recognition, use or cultivation.

\section{EVIDENCE FROM VERNACULAR PLANT NAMES}

To supplement the historical and literary record, in this and subsequent sections we add a variety of linguistic and botanical evidence - inspired by the presence of the epithet marron(ne) in so many plant names on Réunion. Descriptive, emotive and symbolic vernacular names are useful clues for deepening our knowledge of historical and contemporary societies and environments. For instance, Judith Carney and Richard Rosomoff add evidence from plant names to their investigation of the slave trade's

\footnotetext{
${ }^{47}$ Ève, Les esclaves de Bourbon, pp. 130-1.

${ }^{48}$ Backhouse, Narrative, p. 52.
} 
botanical legacy in the Americas. ${ }^{49}$ Likewise, historical linguists analyse the names of common food plants (among other widespread words) across different vernacular tongues in order to decipher human migrations, trade relations and plant dispersal events. ${ }^{50}$ Furthermore, ethnobotanists use plant folk names to analyse how different societies classify, understand and interact with the natural world. ${ }^{51}$

\footnotetext{
${ }^{49}$ Judith Carney and Richard Rosomoff, In the Shadow of Slavery: Africa's Botanical Legacy in the Atlantic World (Berkeley: University of California Press, 2009).
}

${ }^{50}$ Karl Alexander Adelaar, 'Malagasy CultureHistory: Some Linguistic Evidence' in Julian Reade (ed.) The Indian Ocean in Antiquity, pp. 487-500 (London: Kegan Paul International, 1996); L. Campbell, Historical Linguistics (Cambridge, MA: MIT Press, 1999); Roger Blench, 'The Austronesians in Madagascar and Their Interaction with the Bantu of the East African Coast: Surveying the Linguistic Evidence for Domestic and Translocated Animals', Studies in Philippine Languages and Cultures 18 (2008): 18-43; Tom Hoogervorst, 'If Only Plants Could Talk...: Reconstructing Pre-Modern Biological Translocations in the Indian Ocean', in Satish Chandra and Himanshu Prabha Ray (eds) The Sea, Identity, and History: From the Bay of Bengal to the South China Sea, pp. 67-92 (New Delhi: Manohar Publishers, 2013); Rangan et al. 'New genetic and linguistic analyses show ancient human influence on baobab evolution and distribution in Australia', (under review, 2014).

${ }^{51}$ Gabriel Lefèvre, 'Sur la classification vernaculaire des plantes dans le sud-ouest de Madagascar', Études Océan Indien 42-43 (2009): 175-99; Harold C. Conklin, 'Lexicographical treatment of folk taxonomies', in Fred W. Householder and Sol Saporta (eds)

Problems in Lexicography, pp. 119-41 (Bloomington: Indiana University Research Center in Anthropology, Folklore and Linguistics, 1967); Brent Berlin, 'Folk systematics in relation to biological classification and nomenclature,' Annual Review of Ecology and Systematics 4 (1973): 259-71; B. Berlin, Ethnobiological Classification
What we do is the following. First, we investigate the etymology of the adjective marron, and place its analysis in the context of other adjectives used in plant names. Plant names can reflect the cultural, symbolic and ritual significance of the plants themselves. ${ }^{52}$ But, like toponyms, these names can be descriptive or pragmatic, but also commemorative, symbolic or reflective of different aspirations. Studies of toponyms show that names evoke certain ideas and certain discourses, meanings are plastic, the act of naming can be political and interpretations change over time. ${ }^{53}$

Then, in the section that follows, we introduce botanical databases as a data source for vernacular plant names, and discuss the many caveats that need to accompany such analyses. We establish a typology of potential explanations for the use of the adjective marron(ne) in plant names on Réunion, which, in the penultimate section, we apply to a subset of 22 of the 141 marron plants identified in the database. In addition, we identify three dozen plants whose creole names have Malagasy origins,

(Princeton: Princeton University Press, 1992).

${ }^{52}$ Philippe Descola, Par-delà Nature et Culture (Paris: Gallimard, 2005); Laura Rival(ed.) The Social Life of Trees: Anthropological Perspectives on Tree Symbolism (Oxford: Berg, 1998); Helen Anne Curry, 'Naturalising the exotic and exoticising the naturalised: Horticulture, natural history and the rosy periwinkle', Environment and History 18 (2012): 343-65.

${ }^{53}$ Stephen Jett, 'Place-naming, environment, and perception among the Canyon De Chelly Navajo of Arizona', The Professional Geographer 49 (1997): 481-93; Sylvain Guyot and Cecil Seethal, 'Identity of place, places of identities: Change of place names in post-Apartheid South Africa', South African Geographical Journal 89 (2007): 55-63. 
cross-checking them with the botanical databases. In the end, we draw together our analysis of the descriptive, emotive or symbolic meanings of these names with other historical, archaeological, ethnographic and botanical sources in order to highlight certain plants as most likely candidates for further investigation.

\section{THE MEANING OF MARRON(NE) IN PLANT NAMES}

To determine the outer boundaries of a word's known meanings the first place to begin is a dictionary. Aside from their better known uses for chestnuts and for a colour, the French marron(ne) in French and the English equivalent maroon both refer to escaped slaves, with the word originating in the early colonial period in the Caribbean, perhaps from cimarrón ('wild, unruly', based on old Spanish for 'thicket'). In both languages, the word has also been applied to escaped domestic animals, like feral cattle or pigs. Indeed, on Mauritius Milbert describes his encounter with 'an enormous wild pig (cochon-marron)' and Pike writes that 'the wild boar ... belongs to the race called cochons marrons, supposed to be descendants of domestic pigs escaped to the woods at a very early period' ${ }^{54}$ In both languages again, it can be a transitive verb describing the abandonment of someone or something ashore in a position from which they cannot escape. In addition, the word in French can be used to qualify someone

\footnotetext{
${ }^{54}$ Ibid., vol. 1, p. 296; Pike, Sub-Tropical Rambles, p. 219.
}

illegally practicing a profession, e.g. an imposter. 55

A more concrete way to frame an analysis of marron/marronne as a possible linguistic clue to slave agency in shaping the landscapes of the Mascarenes is to look at parallel examples of the use of adjectives or qualifiers in plant names that indicate origins or associations with particular people. In all cases, they can be used to distinguish between plants of the same genus, between varieties of the same species or between plants of similar usage. In the Americas, an obvious example is the adjective guinea denominating African origin, for guinea grass, guinea bean and so on. ${ }^{56}$ In the Mascarenes, similar descriptors include malgache (from Madagascar, e.g. grain malgache, pistache malgache, raisin malgache, brède malgache, bois malgache) and malabar (prune malbare, oseille malabare) and others (bois kaf kaf, bois Malaya, bois Mozambique, bois d'olive des Seychelles). ${ }^{57}$

In Madagascar, the most obvious parallels to marron's connotation of

\footnotetext{
${ }^{55}$ One might conjecture that this latter definition could be attributed to the perceptions by planters of their slaves who had escaped in the wild, and hence had no more economic utility. Definitions checked at following sites:

www.collinsdictionary.com/dictionary/american/ cimarron; www.cnrtl.fr/definition/marron; www.oed.com; and

http://ecrit.creole.free.fr/lexique.html (accessed 8 Aug. 2013).

${ }^{56}$ Carney and Rosomoff, In the Shadow of Slavery. p. 103.

${ }^{57}$ Database of the Conservatoire Botanique National de Mascarin (http://flore.cbnm.org/ (accessed 19 May 2012); Louis J. Thérésien Cadet Plantes rares ou remarquables des Mascareignes (Paris: Agence de coopération culturelle et technique,1984).
} 
'wild' are the adjectives dia (wild) and voanjanahary (wild, literally 'fruit of God'). Parallels to the use of marron for a specific group of people are the qualifiers gasy, vazaha and manga. These terms are used in several ways. Gasy, which means from Madagascar, tends to refer to older types of plants, whether wild or cultivated, that are then contrasted with newer arrivals, whether cultivars of the same species, of related species or of altogether different species but with similar characteristics. These are often called vazaha, given their association with the colonial period, development projects or with agricultural extension efforts. Examples include voatavo (calabash gourd) versus voatavombazaha (pumpkin); paiso gasy (plum) versus paisombazaha (peach, or specifically grafted peach); and tavolo gasy (Tacca pinnatifida, famine food) versus tavolo vazaha ('real' arrow root). ${ }^{58}$ Plant names with the qualifier

\footnotetext{
${ }^{58}$ Further examples include vary (rice) versus varimbazaha (wheat); angivy (Solanum erythracanthum, a native nightshade family plant) versus angivimbazaha (eggplant), and anamamy (local leafy greens) versus anamamimbazaha (spinach and tetragonia). Based on P. Boiteau, M. Boiteau and L. AllorgeBoiteau, Dictionnaire des noms malgaches de végétaux, 4 vols. (Grenoble: C. Alzieu, 1999); Christian Kull, Jacques Tassin, Sophie Moreau, Hervé Rakoto Ramiarantsoa, Chantal BlancPamard and Stéphanie Carrière, 'The introduced flora of Madagascar', Biological Invasions 14 (2012): 875-88; Raison 'L'introduction du manioc à Madagascar', p. 227. For manga, Hébert speculatively lists voanjomanga (type of ground nut), voamanga (watermelon), aikamanga (a type of indigo), tanatanamanga (castor oil), and varimanga (varieties of rice). See Jean Claude Hébert, 'Manga > Olomanga, Ramanga, Antemanga $>$ Zazamanga, Zafimanga', in Claude Allibert and Narivelo Rajaonarimanana (eds) L'extraordinaire et le Quotidien. Variations Anthropologiques. Hommage au Professeur Pierre Vérin, pp. 387421 (Paris: Karthala, 2000).
}

manga, according to Jean Claude Hébert, reflect origins via 'Arabs', i.e. the trading routes linking Madagascar to the Swahili coast. ${ }^{59}$ Other appellations can be applied to origins of specific cultivars of common plants, such as cassava (mangahazo) being gasy, masombika (Mozambique) or boribona (Réunion), or modern rice from Pakistan, China or Brazil. $^{60}$

These appellations can also have secondary meanings associated with them. ${ }^{61}$ Hébert hypothesises that the Arab origins of the epithet manga have often been forgotten, and the other meanings of the word (good, sacred or blue) attached to the plants. For merchants and urban consumers, the use of gasy for rice is a first level distinction made about 'fresh' locally grown rice of local varieties (as opposed to drier stock rice, whether old local rice or imported). The contrast between tongologasy (garlic), tongolo (onions), and tongolombazaha (small-bulbed European onions) goes beyond the antiquity of each cultivar. Given that villagers often equate gasy with poor quality and vazaha with high quality (perpetuating colonial mentalities as

\footnotetext{
${ }^{59}$ Hébert 'Manga > Olomanga'.

${ }^{60}$ Ibid.; Douglas Hume, 'Vary gasy: Folk models of rice and implications for agricultural development in eastern Madagascar', Études Océan Indien 42-43 (2009): 243-56.

${ }^{61}$ Hébert, 'Manga > Olomanga'; Boiteau, Dictionnaire; Hume, 'Vary gasy...' Another example is dingadingana and dingadingambazaha, both of which refer to pioneer plants found in fallow fields sometimes used as hedge plants, the former being native (Psiadia altissima) while the latter is an alien invasive (Justicia gendarussa). Dingadingana itself means strolling or travelling, so together with the epithet vazaha the meaning tends towards invasive alien or feral.
} 
well as matter-of-factly noting differences in manufactured goods due to the massive gulf of development levels), it may be - and villagers jokingly speculated this to one the authors - that garlic is called gasy as it is more pungent than pure onions.

What we can see is that epithets that purportedly refer to places, status or social groups can give hints of a plant's past, but that they can be inconsistently applied and might reflect a variety of sometimes-confused origins and additional layers of meaning ('fresh', 'feral', 'pungent'). As the example of garlic indicates, the use of a descriptor may incorporate prevailing social discourses. Similarly, Anna Tsing has shown how the name 'Africanized' honeybee, which was applied to an invasive newcomer in the United States, contains multiple layers of gendered and racist connotations. So we must keep such possibilities in mind for marron/marronne. ${ }^{62}$

Another important point is that the epithet 'marron(ne)' for plants appears to have emerged during the early or middle 1800 s, perhaps in reaction to the increasing occurrence of human marronnage and the popularization of stories about it. It is possible that this

\footnotetext{
${ }^{62}$ The social value of certain epithets is made clear by the following Malagasy example. Certain descendants of slaves in the highlands claim vazimba ancestry (vazimba is a vague term for pre-Merina hunter-gatherers) in order to stake claim to burial sites. See David Graeber, Lost People: Magic and the Legacy of Slavery in Madagascar (Bloomington: Indiana University Press, 2007). On honeybees, see Anna Tsing, 'Empowering nature, or: Some gleanings in bee culture', in S. Yanagisako and C. Delaney (eds) Naturalizing Power. Essays in Feminist Cultural Analysis, pp. 113-43 (New York: Routledge, 1995).
}

usage first took place with feral animals (the cochons marrons mentioned earlier in the descriptions of Milbert in 1812 and Pike in 1873), ${ }^{63}$ before taking hold in the plant world. Our reasoning is that the epithet does not seem to appear in the literary or documentary record for plants in the Mascarenes before Baker noted it in a wide number of vernacular names in $1877 .^{64}$

\section{VERNACULAR NAMES IN BOTANICAL DATABASES}

At this point, it behoves us to present a cautionary note about making inferences from vernacular names, particularly those in botanical databases, many of which are now easily available online. Many such databases of flora, while based on scientific names (themselves often changing and contested), list common names for the plants they describe. Two major caveats apply to these lists of common names. First, they tend to come with only minimal context, as far as where or when such names are (or were) used, by whom (which language group or social group) or how common this usage is with respect to other names. The database we relied on is a modern creation based on floras published 150 years after slavery ended. ${ }^{65}$ We noted above how bananas used to be called figs, and the confusion this causes. Strictly speaking, such local names are recorded on the information sheets that botanists append to their

\footnotetext{
${ }^{63}$ Milbert, Voyage pittoresque, vol. 1, p. 296; Pike, Sub-Tropical Rambles, p. 219

${ }^{64}$ Baker, Flora.

${ }^{65}$ Vincent Boullet, Notice de l'Index de la Flore Vasculaire de la Réunion, http://flore.cbnm.org/download/Notice Flore El ectronique 2010.1.pdf (accessed 29 Jul. 2014).
} 
samples stored in herbaria; compilers of regional or national flora then assemble this information by searching through these herbaria specimen and adding their own local knowledge. This information then makes its way to online databases, with further abstractions and simplifications. The second caveat is that once a list is established, it takes on a life of its own, as it is copied and recopied, compiled and recompiled into an ever-expanding universe of databases that borrow information from each other. Context is further removed.

One example suffices. The thorny, American shrub Acacia farnesiana was likely introduced to Fiji in the 1800s as an ornamental (it is also found in Madagascar and Réunion, probably through a similar colonial pathway). According to numerous online flora and weed databases, a common name for this plant in Fiji (sometimes, the only common name listed for Fiji) is 'Ellington's curse'. Yet locals do not use that name. In Rakiraki, where the scrubby, multi-branched plant is most common and grows along roads, at the edges of sugar cane fields, and particularly in pastures, the locallydominant Indo-Fijian farmers call it 'katta' (thorn) or 'baburi' (similar to 'babul', used in India for other thorn trees). ${ }^{66}$ To hazard a guess, it is not unlikely that the name 'Ellington's curse' was coined by a colonial-era cattle station owner or government agricultural officer - a district and wharf in Rakiraki are called Ellington,

\footnotetext{
${ }^{66}$ Based on conversations with one of the authors in 2011 and 2013, and confirmed by Albert Smith's Flora Vitiensis Nova (Hawaii: Pacific Tropical Botanical Garden, 1985). According to Smith, Fijian names for the plant include 'walaulau', 'vaivai vakavotona' and 'oka'.
}

presumably after a colonial settler or administrator - and entered the published floras of the island through that route. The use of this name in Fiji is likely limited to a few government land managers and expatriate ecologists. But as this is a particularly evocative moniker for this thorny plant - declared a noxious weed in many parts of the world - the name has taken wings of its own.

The conclusion for us is that we should not read too much into specific uses of adjectives like marron for plants. However, at a general level, it is certainly still significant that so many plant taxa have this adjective appended to them in the Conservatoire Botanique National de Mascarin database we evoked in our opening lines. From this observation, we have sought in an earlier section to link it to the prevalence of the idea of marronnage in popular discourse. For specific plants on this list, the moniker serves merely as a hint to dig deeper using other types of sources. This is where, for example, the work of linguists and ethnographers may come in handy, particularly if they have sufficient botanical knowledge to distinguish between different plants. ${ }^{67}$

Although this exercise so far provides no answers to the origins of colloquial plant nomenclature at Réunion, it does show that fugitive slaves - maroons loomed large in the popular imaginary of the island's inhabitants. Moreover, as

\footnotetext{
${ }^{67}$ Good examples of combined linguistic and botanic work include: Boiteau et al. Dictionnaire Des Noms Malgaches De Végétaux and Ronald Gatty, Fijian-English Dictionary with Notes on Fijian Culture and Natural History (Suva: R. Gatty and Ithaca: Cornell SEAP, 2009). https://ecommons.library.cornell.edu/handle/181 $3 / 28702$.
} 
Prosper Ève emphasises, 'the maroon was a true pioneer' in penetrating the mountainous forest frontier of Réunion. ${ }^{68}$ Reflecting on the lessons from our review of vernacular plant names above, together with the specific circumstances of the Mascarenes, suggests four possibilities for how so many plants on Réunion came to be designated marron(ne).

1. First, a plant could be somehow associated with maroons or, more broadly, with the Afro-Malagasy slave population, e.g. used, eaten, grown, or more tenuously - transported by them, to the point that it became known as marron.

2. Second, a plant that escaped from gardens and went 'feral' so that it established itself in the mountains (or anywhere on the island, for that matter) might become identified as being marron. This interpretation reflects a metaphorical use of marron.

3. Third, given dominant social discourses about maroons, a native or naturalized introduced plant that reminded people of a more familiar plant or cultivar might have come to be called marron for being 'wild' (Category 3a) and, in some cases, for being an 'imposter', or not offering the same quality of food or other use one would expect from its better-known relative (Category 3b).

4. Four, a cultivated plant that, similar to Category 3, reminds people of a more familiar plant but which does not have the same use.

We also considered some other possible explanations. One is that the epithet

\footnotetext{
${ }^{68}$ Ève, Les esclaves de Bourbon, pp. 118-19. Ève especially emphasises the contribution of maroons to the pharmaceutical traditions of the island, for which see ibid., pp. 325, 327-8.
}

marron(ne) arrived together with a plant from the West Indies or Guyana. To our knowledge, only the Vanillier marron (Duranta erecta) and the Pistache marronne bleue (Clitoria ternatea, pwa mawon in the West Indies) carry the same (or similar) common names in the West Indies and Réunion, fitting this possible explanation. ${ }^{69}$ Another is that marron(ne) refers to either the colour of the plant or its parts, an option that we consider unlikely given the cultural importance of the category marron in Réunion. In what follows, we examine a number of other plants that bear the tag marron to see if they fall into one or more of these possible explanatory categories.

\section{TRACING STORIES OF INDIVIDUAL PLANT SPECIES}

We investigated in further detail certain plants from the list of 114 marron/marrone names from the Conservatoire Botanique National de Mascarin (see note 2 and Appendix 1) for which the ethnographic or botanical literature provides interesting or illuminating hints of relevance to our paper. We also cross-referenced these plants with those listed in John Baker's 1877 compilation of flora of Mauritius and the Seychelles. ${ }^{70}$ We did not include plants for which information is scarce or

\footnotetext{
${ }^{69}$ Jacques Fournet, Flore illustrée des phanérogames de Guadeloupe et de Martinique, Tomes 1 et 2 (Petit-Bourg, Guadeloupe : INRA, 1978). Fournet's flora includes eight plants with the epithet marron(ne) and 65 plants with the creole version, mawon.

${ }^{70}$ John Gilbert Baker, Flora of Mauritius and the Seychelles: a Description of the Flowering Plants and Ferns of those Islands (London: J. Reeve, 1877), accessed on Gallica, 28 Jan. and 13 Mar. 2014.
} 
for which the meaning of marron remains enigmatic. ${ }^{71}$ For each plant, we examined whether the use of marron fits in one of the above four categories. This was difficult, given the absence of detailed historical data for most of them. In addition, some plants may qualify for multiple categories. For instance, useful plants that escaped from cultivation (category 2) were likely used by maroons (category 1). However, triangulating between different sources botanical evidence, ethnographic information on the use of the plants elsewhere in Africa or Madagascar, and what historical evidence exists - helps us develop robust hypotheses. ${ }^{72}$

- The subspecies africanus of Abrus precatorius (Réglisse marronne) is widely distributed in Africa, but is also native to Madagascar and the Mascarenes. In Mauritius it was known

\footnotetext{
${ }^{71}$ Some vernacular names with the epithet marron(ne) remain enigmatic. For instance, zamal marron, which refers to Conyza spp., clearly labels these plants as a 'marron' version of zamal, Cannabis sativa., but all the parts of the two plants are quite different and, to our knowledge, Conyza species have no psychoactive effects. The creole word zamal for Cannabis apparently comes from Malagasy, though the origins are obscure (Chaudenson, Le Lexique, p. 531). Similarly, the name jaque marron for Cordemoya integrifolia also remains enigmatic, as this tree has no similarity with the jackfruit, Artocarpus heterophyllus, except that the leaves have a similar ribbing, though they really cannot be confused.

${ }^{72}$ Key sources for this list include Cadet, Plants rares; Kull, 'Introduced flora of Madagascar'; Claude Marcel Hladik, Annette Hladik, Hélène Pagezy, Olga F. Linares, Georgius J.A. Koppert and Alain Froment (eds) L'alimentation en forêt tropicale, interactions bioculturelles et perspectives de développement (Paris: Editions UNESCO, 1996).
}

simply as réglisse ${ }^{73}$ in Réunion it is also known as 'cascavelle'. The plant has ornamental bright red seeds used as jewellery, though they are toxic. There are reports of trans-Atlantic slaves wearing and retaining necklaces of Abrus seeds. ${ }^{74}$ The leaves and roots are consumed in Africa. ${ }^{75}$ The reference to réglisse (Glycyrrhiza glabra) may come from similarities in the leaves, both species belonging to the pea family. Accordingly, the term marron may refer to Categories 1, 2 and 3.

- Aloe macra (mazambron marron) is an aloe endemic to Reunion which is rather similar to Aloe vera (mazambron) but without providing the medicinal uses of A. vera. The vernacular name likely refers to Category 3.

- Ananas bracteatus (ananas marron, ananas sauvage) is an ornamental pineapple with an edible red fruit, reputed to be a laxative. The plant is naturalised and may have been consumed by maroons. Likely category 3.

- Astelia hemichrysa, also called ananas marron, is a native epiphyte whose leaves and fruits somewhat resemble pineapple, but it is not edible. The name likely refers to Category 3.

- Cajanus scarabaeoides (fausse pistache marronne), the wild pigeon pea, is native to Madagascar and could have been introduced from there by enslaved Malagasy and would certainly have been

\footnotetext{
${ }^{73}$ Baker, Flora, pp. 78-79.

${ }^{74}$ Carney and Rosomoff, In the Shadow of Slavery. p. 212.

${ }^{75}$ Matchu M. Dhetchuvi and Jean Lejoly, 'Les plantes alimentaires de la forêt dense du Zaïre, au nord-est du Parc National de la Salonga', in Hladik, L'alimentation en forêt tropicale, pp. 301-314.
} 
recognised and perhaps used by them (Category 1), but the name also refers to the 'real' pigeon pea, Cajanus cajan (so Category 3 is also possible). Cajanus cajan is known in creole as 'ambrevade', which comes from the Malagasy 'ambarivatry', suggesting the plant was of importance to Malagasy slaves and marrons.

- Canna indica. Like the better-known cultivated Canna edulis, the naturalised 'safran marron' also provides edible roots. ${ }^{76}$ It was also well established on Mauritius in the nineteenth century. ${ }^{77}$ Since these roots cannot be confused with saffron bulbs (Crocus sativus), which are quite different plants, it is likely that the epithet marron does not refer to category 3 or 4, but may instead refer to Category 1 or 2.

- Centella asiatica (violette marronne) is a renowned medicinal species that grows in many areas, including Africa. While the dispersal of this plant has been linked to human migrations in general, ${ }^{78}$ the epithet marronne more likely falls in Category 3 as the leaves are similar to those of the violet (though the flower has a lower ornamental interest).

- Coffea mauritiana (café marron) is a native variety of coffee, likely Category 3 . It is also recorded for Mauritius. ${ }^{79}$

\footnotetext{
${ }^{76}$ http://www.eattheweeds.com/cannaconfusion/ accessed 7 Aug. 2013.

${ }^{77}$ Baker, Flora, p. 327.

${ }^{78}$ Saoharin'ny Ony Raoseta Rakotondralambo et al., 'Insight into the Biology, Genetics and Evolution of the Centella Asiatica Polyploid Complex in Madagascar', Industrial Crops and Products 47 (2013): 118-25.

${ }^{79}$ Baker, Flora, p. 46, also pp. 141-2 for another plant (Randia heterophylla), apparently on the island of Rodrigues, carrying this name; see also
}

- Crotalaria retusa (pois rond marron) is naturalised on Réunion and may have been consumed by maroons. The seeds are also known to be consumed in Africa, and the creole name of the related plant Crotalaria uncinella (ambrevatte marron) builds on a Malagasy term referring to the edible Cajanus cajan (see above).$^{80}$ Both types of Crotalaria are common in

Madagascar. This genus is thus likely to be an example of Category 1.

- Cucumis anguria (concombre marron) is a kind of cucumber native to East and Southern Africa. Immature fruits can be eaten, as can the leaves (when cooked). The plant is rare today but, if it was more widespread in the past, it could have been collected by fugitive slaves. Baker records it for Mauritius. ${ }^{81}$ Thus possibly Category 1 , but more likely Category 3. We note that an old creole word for another kind of melon was 'vatangue', from the Malagasy 'voatango'. 82

- Cyclospermum leptophyllum (anis marron), a naturalised plant, is similar to aniseed (Pimpinella anisum) and its name can be thus assigned to category 3 .

- Duranta erecta (vanillier marron) is an ornamental shrub with vanilla-scented flowers which is only cultivated in

the identification of Café marron as Coffea macrophylla in E.J. Adjanohoun (ed.) Contribution aux études ethnobotaniques et floristiques à Maurice (Iles Maurice et Rodrigues) (Paris: Agence de Coopération Culturelle et Technique, 1983) p. 206, but with no detailed description of the plant.

${ }^{80}$ http://flore.cbnm.org/ (accessed 5 Aug. 2014). Dhetchuvi and Lejoly, 'Les plantes alimentaires de la forêt dense du Zaïre...'.

${ }^{81}$ Baker, Flora, p. 131.

${ }^{82}$ Chaudenson, Lexique, p. 529. 
gardens. The flowers and fruits are toxic for human beings. ${ }^{83}$ It fits in Category 4 , but as noted above is it also a candidate for transfer of the plant and/or its name from the West Indies.

- Flacourtia indica (prune malgache, sometimes prune malgache marronne), is native to both Africa and Asia. Its edible fruits are still eaten by creoles on Reunion, and elsewhere. ${ }^{84}$ It may have been introduced by slaves or 'indentured workers' from Madagascar or East or Southern Africa, though it seems to have been cultivated before 1771 on Réunion. A related plant, Flacourtia ramontchi, was called prunier marron in the Seychelles. ${ }^{85}$ We suggest that this plant species may refer to Category 1.

- Hibiscus boryanus (foulsapate marron) is a beautiful and rare endemic ornamental hibiscus, similar to the wellknown Hibiscus rosa-sinensis, which was locally named foulsapate during the eighteenth century. ${ }^{86}$ Its 'wild' status suggests Category 3 is most likely.

- Hyophorbe verschaffeltii (palmiste marron). The terminal bud (chou) is bitter and the sap can cause vomiting,

\footnotetext{
${ }^{83}$ http://www.mi-aime-aou.com/vanillier marron vanillier de cayenne. php (accessed 7 Aug. 2013).

${ }^{84}$ Kailash C. Malhotra, 'Biodiversité et problème de reconstitution des forêts tropicales au Bengale Occidental (Inde)', in Hladik et al., L'alimentation en forêt tropicale, pp.1155-63.

${ }^{85}$ Baker, Flora, p. 12.

86 Annegret Bollée, Dictionnaire étymologique des créoles français de l'Océan Indien, Vol. 1, Parts 1 to 4 (Hamburg: Buske, 1993) p. 137. Milbert, Voyage pittoresque, p. 50, describes a plant 'named foul-sapate, of which the flowers are bell-shaped (campaniformes)', that he observed near Pamplemousses. Baker, Flora, pp 22-5 lists numerous varieties of Hibiscus, but not Hibiscus boryanus.
}

which makes this native species of palm not edible, in contrast to other palms like Dictyosperma album and Acanthophoenix rubra that are greatly appreciated on Réunion. Baker identified it on Mauritius by the same vernacular name. ${ }^{87}$ The name palmiste marron clearly refers to a misleading and frustrating - appearance (Category $3)$.

- Passiflora foetida (grenadier marron). The wild maracuja or bush passionfruit is native to South America, and might have naturalised in Africa before being introduced to Réunion and Madagascar, where it has also naturalised. Its fruit is edible and tasty, though rarely eaten, probably because the other parts of the plant do not have a pleasant odour. According to Baker, it was only 'occasionally sub-spontaneous in Mauritius' and not known by this popular name. ${ }^{88}$ In the Democratic Republic of Congo, these fruits are reserved for children ${ }^{89}$. The name grenadier marron may have three different meanings, referring to Category 1 or 2 or 3 .

- Piper sarmentosum (bétel marron). Native to Asia, this 'wild betel' is related to the mild stimulant and medicinal Piper betle, hence Category 3. We note, though, that the related Piper borbonense is known in creole as 'lingue' or 'lingue pwa', another name with possible Malagasy roots. ${ }^{90}$

- Poupartia borbonica (zévi marron) is an

\footnotetext{
${ }^{87}$ Baker, Flora, p. 383.

${ }^{88}$ Ibid., p. 105.

${ }^{89}$ Hélène Pagézy, 'Importance des ressources naturelles dans l'alimentation du jeune enfant en forêt tropicale inondée (Zaïre)', in Hladik et al., $L$ 'alimentation en forêt tropicale, pp.569-88.

${ }^{90}$ Chaudenson, Lexique, p. 508.
} 
endemic tree of the Mascarenes which produces fruits reminiscent of zevi (Spondias dulcis) fruits, and which are also edible. Another species of Spondias is the sakoa ( $S$. caffra), consumed in Madagascar. This suggests that the name of zevi marron may have been given to Poupartia borbonica because it was eaten by Malagasy maroons familiar with sakoa (Categories 1 and 3).

- Rubus alceifolius (raisin marron, vigne marronne). The giant bramble, with edible fruit, comes from South-east Asia and was introduced around 1840 to Reunion. ${ }^{91}$ It is naturalised on Reunion, Mauritius and Madagascar. Its presumed arrival is too late to have been carried by enslaved Africans or for it to have served as food for the maroons. Most likely, the term raisin marron refers to the general appearance of this liana and its leaves, distantly reminiscent of grapes (hence Category 3).

- Solanum macrocarpon (petite bringelle marronne). A West African native, this plant is common across Africa; it is used as a vegetable, but also in traditional medicine. It may have been cultivated on Réunion, then become naturalised. It is similar to eggplant (also known as aubergine and brinjal), both being in the nightshade family. It is thus a candidate for Categories 1, 2 and 3.

- Solanum mauritianum is named tabac marron or brungellier marron. The former name refers to a similarity of its leaves with those of tobacco (Nicotiania tabacum), and the latter refers to a similarity of its flowers and fruits with those of eggplant (Solanum melongena). Both names can be assigned to Category 3.

\footnotetext{
${ }^{91}$ Emile Jacob de Cordemoy, Flore de l'île de La Réunion (Paris : Klincksiek Éditions, 1895).
}

- Terminalia arjuna (bois carambole) provides non-edible fruits which evoke those of the star fruit or carambola (Averrhoa carambola L.). Both species are cultivated only, hence we assign Category 4.

From this selective exercise, we see that the most common explanatory category for marron/ne plant names refers to wild plants that are similar to a known species or variety (Category 3 ), applying to sixteen of our 21 profiled plants. For many of these, their utility is less than that of the known species, though for people eking out a survival existence in the hills, it is likely that something edible was better than nothing. As ethnobotanists and others have noted, many wild plants play a role during famine periods. ${ }^{92}$ As far as Category 1 , which provides the most exciting potential for discovering the agency of maroons in shaping the environment of the Mascarenes, we identified eight potential plants: Abrus precatorius, Cajanus scarabaeoides, Canna indica, Crotalaria retusa, Flacourtia indica, Passiflora foetida, Poupartia borbonica, and Solanum macrocarpon.

To complement the above approach, we investigated other linguistic clues, specifically the existence of Reunnionaise creole names for plants that have Malagasy origins and thus hint at a possible role of Malagasy slaves in introducing, using, or propagating them. In Robert Chaudenson's authoritative creole lexicon, 35 , or one third, of the 108 entries for words with Malagasy

\footnotetext{
${ }^{92}$ Martin Walsh, 'The Use of Wild and Cultivated Plants as Famine Food on Pemba Island, Zanzibar', Études Océan Indien 42-32 (2009): 217-241.
} 
roots are plant names (see Appendix 2). ${ }^{93}$ This in itself shows the importance of a Malagasy contribution to local vegetation. Of the 35 plants, five are derived from Malagasy descriptor words, whereas the thirty others appear to be the plant names from Malagasy dialects. Seven of the 35 plants overlap with our list of plants with 'marron/ne' in the common name. We have noted some of these above, particularly Cajanus, Crotalaria, Cucumis, and Piper.

A number of other plants with Malagasy-origin creole names are among the food plants of marooned slaves we described from historical sources, adding credence to the hypothesis for Malagasy agency in their introduction, use or propagation. These include some discussed earlier, like yams (Dioscorea alata), taro (Colocasia esculenta) and vavangue (Vangueria madagascariensis). In addition to these obvious leads, five additional plants with Malagasy names, selected for their ubiquity, importance or familiarity, appear ripe for further investigation: the ginger lilies (Hedychium spp.), the traveller's palm (Ravenala madagascariensis), the castor bean (Ricinus communis), the cowpea (Vigna unguiculata) and the hyacinth bean (Lablab purpureus). Records of the latter, for instance, appear very early in slave societies in the Americas. ${ }^{94}$

\footnotetext{
${ }^{93}$ Chaudenson, Lexique; also Daniel Baggioni, Dictionnaire Créole Réunionnaise - Français. (Réunion, Azalées Éditions, 1990). We crosschecked plant references with the online floras of CBNM (http://flore.cbnm.org) and Tropicos (http://www.tropicos.org/Project/MADA), accessed 3-5 Aug. 2014.

${ }^{94}$ Carney and Rosomoff, In the Shadow of Slavery, p. 124.
}

\section{CONCLUSION}

Beginning from the premise that the large collection of marron(ne) vernacular plant names in the Mascarenes may reveal something about the role of marooned slaves in the landscapes of those islands, we sought to piece together the evidence. This brought us to consider the historical record, to investigate period literature, to seek inspiration from ethnolinguists and allied fields and to dig in botanical databases. From these sources, we have ascertained a number of key points. First, maroons certainly relied on a variety of wild, escaped and cultivated plants for their subsistence. Second, the presence of grand maronnage in mountainous Réunion left an indelible imprint in the popular discourses of the island, both critical and romanticised. Third, the plethora of marron and Malagasy vernacular plant names reflects this discourse and, in some isolated cases, might point us to specific plants that were transported, cultivated or encouraged in one way or another by maroons. Finally, and more generally, vernacular names can be useful clues, but both the records of these names and the meanings of the names themselves can be inconsistent and changing, requiring careful multidisciplinary investigation and triangulation.

Our own marooning adventure suggests a number of tracks for future research. The eight category 1 marron plants we identified, as well as the key Malagasyorigin plants named above, deserve further investigation. More attention should be given, we contend, to other linguistic clues, particularly in the local creole. We have focused on Malagasy etymological roots in Reunionnaise creole plant names, but there may also be African influences worth following 
up. Furthermore, detailed ethnographic research, such as that reflected in Martin Walsh's exploration of wild and cultivated plants as famine foods in Pemba, can provide multiple insights to deepen and strengthen conjectures and hypotheses like our own. Finally, genetic advances in biogeographical and botanical research, such as those behind Xavier Perrier et al.'s review of banana domestication and movement, can be used to corroborate or disprove particular ideas about particular plants. ${ }^{95}$ Most important, however, is the spirit of multi- and trans-disciplinary investigation, where scholars triangulate between multiple sources of evidence focused on a specific problem. Otherwise, the ship of inspiration will remain marooned on a distant, desert isle.

\section{ACKNOWLEDGEMENTS}

We thank Judy Carney and Priya

Rangan for inspiring and facilitating this collaboration, and the editors and reviewers for their constructive suggestions on the manuscript.

\section{REFERENCES}

See footnotes

\footnotetext{
${ }^{95}$ Walsh, 'The Use of Wild and Cultivated Plants as Famine Food'; Xavier Perrier and 17 others, 'Multidisciplinary Perspectives on Banana (Musa Spp.) Domestication', Proceedings of the National Academy of Sciences 108/28 (2011): 11311-18.
} 


\section{APPENDIX 1.}

List of plant species of Réunion with marron/maronne in their local vernacular name. Note that the plant may also be known by other local names. Source: database of the Conservatoire Botanique National de Mascarin (http://flore.cbnm.org/, accessed 19 May 2012).

\section{Vernacular name}

Ail marron

Ambrevatte marron

Ananas marron

Ananas marron

Anis marron

Avocat marron

Avocat marron à grandes feuilles

Avocat marron à petites feuilles

Bec zozo marron

Bec zozo marron

Bétel marron

Bois café marron

Bois de buis marron

Bois de café marron

Bois de cannelle marron

Bois de cannelle marron à petites feuilles

Bois de chandelle marron

Bois de chandelle marron

Bois de chandelle marron

Bois de jaque marron

Bois de mangue marron

Bois de mangue marron

Bois de mangue marron

Bois de marron

Bois de pêche marron

Bois de pêche marron

Bois de pêche marron

Bois de pêche marron

\section{Botanic name}

Nothoscordum inodorum (Aiton) G. Nicholson

Crotalaria uncinella Lam.

Ananas bracteatus (Lindl.) Schult. et Schult. f.

Astelia hemichrysa Lam.

Cyclospermum leptophyllum (Pers.) Sprague ex Britton et P. Wilson

Litsea glutinosa (Lour.) C. Rob.

Litsea monopetala (Roxb.) Pers.

Litsea glutinosa (Lour.) C. Rob.

Polygala virgata Thunb.

Polygala virgata Thunb. var. decora (Sond.) Harv.

Piper sarmentosum Roxb.

Turraea oppositifolia (Cav.) Harms

Grangeria borbonica Lam.

Turraea thouarsiana (Baill.) Cavaco et Keraudren

Ocotea obtusata (Nees) Kosterm.

Ocotea obtusata (Nees) Kosterm.

Badula borbonica A. DC.

Badula borbonica A. DC. var. borbonica

Badula borbonica A. DC. var. macrophylla (Cordem.) Coode

Badula grammisticta (Cordem.) Coode

Pittosporum senacia Putt.

Pittosporum senacia Putt. subsp. reticulatum (Tul.) Coode

Pittosporum senacia Putt. subsp. senacia

Psiadia dentata (Cass.) DC.

Eugenia mespiloides Lam

Psiloxylon mauritianum (Bouton ex Hook. f.) Baill.

Securinega durissima J.F. Gmel.

Syzygium borbonicum J. Guého et A.J. Scott 
Bois de prune marron

Bois de prune marron

Bois de prune marron

Bois d'évi marron

Bois marron

Bringellier marron

Bringellier marron

Bringellier marron

Bringellier marron

Café marron

Canne marronne

Cannelle marron

Carambole marron

Carotte marron

Carotte marronne

Citronnelle marron

Concombre marron

Cresson marron

Fausse pistache marronne

Fausse pistache marronne

Figue marron

Fougère marron

Foulsapate marron

Fraise marron

Framboise marronne

Framboise marronne

Girambelle marron

Girambelle marron

Girambelle marron

Girambelle marron

Goyave marron

Grenadier marron

Grosse carambole marronne

Immortelle marronne

Immortelle marronne

Jaque marron

Jaque marron
Myonima obovata Lam.

Myonima obovata Lam. var. longifolia Verdc.

Myonima obovata Lam. var. obovata

Polyscias repanda (DC.) Baker

Psiadia montana (Cordem.) Cordem.

Solanum abutiloides (Griseb.) Bitter \& Lillo

Solanum anguivi Lam.

Solanum mauritianum Scop.

Solanum violaceum Ortega

Coffea mauritiana Lam.

Cordyline mauritiana (Lam.) J.F. Macbr.

Ocotea obtusata (Nees) Kosterm.

Terminalia arjuna (Roxb. ex DC.) Wight et Arn.

Daucus carota L. subsp. carota

Daucus carota L. subsp. carota

Cymbopogon caesius (Nees) Stapf

Cucumis anguria $\mathrm{L}$.

Cardamine africana L.

Cajanus scarabaeoides (L.) Thouars

Desmodium repandum (Vahl) DC.

Ficus mauritiana Lam.

Marattia fraxinea Sm.

Hibiscus boryanus DC.

Duchesnea indica (Andrews) Focke

Rubus apetalus Poir.

Rubus apetalus Poir. var. apetalus

Phyllanthus consanguineus Müll.Arg.

Phyllanthus phillyreifolius Poir.

Phyllanthus phillyreifolius Poir. var. crassistigma Coode

Phyllanthus phillyreifolius Poir. var. phillyreifolius

Aphloia theiformis (Vahl) Benn.

Passiflora foetida L.

Bulbophyllum conicum Thouars

Gamochaeta purpurea (L.) Cabrera

Pseudognaphalium luteoalbum (L.) Hilliard et Burtt

Cordemoya Baill.

Cordemoya integrifolia (Willd.) Pax 
Jaque marron

Lastron marron

Manioc marron du bord de mer

Manioc marron du bord de mer

Mazambron marron

Mourongue marron

Natte marron

Natte marron

Oignon de lis marron

Oseille marronne

Ouatier marron

Palmiste marron

Patate marronne

Petit vacoua marron

Persil marron

Petite bringelle marronne

Petite carambole marronne

Pistache marronne

Pistache marronne

Pistache marronne bleue

Pois rond marron

Pois rond marron

Poivrier marron

Poivrier marron

Pourpier marron

Pourpier marron

Pourpier marron

Prune malgache marronne

Prune marron

Raisin marron

Réglisse marronne

Safran marron

Safran marron

Tabac marron

Tabac marron

Tabac marron

Tabac marron
Cordemoya subg. Cordemoya

Tephrosia purpurea (L.) Pers.

Scaevola plumieri (L.) Vahl

Scaevola taccada (Gaertn.) Roxb.

Aloe macra Haw.

Breynia retusa (Dennst.) Alston

Sideroxylon borbonicum DC.

Sideroxylon borbonicum DC. var. borbonicum

Calanthe sylvatica (Thouars) Lindl.

Begonia salaziensis (Gaudich.) Warb.

Gomphocarpus fruticosus (L.) W.T. Aiton

Hyophorbe verschaffeltii $\mathrm{H}$. Wendl.

Ipomoea nil (L.) Roth

Pandanus sylvestris Bory

Pilea urticifolia (L. f.) Blume

Solanum macrocarpon $\mathrm{L}$.

Bulbophyllum nutans (Thouars) Thouars

Teramnus labialis (L. f.) Spreng.

Teramnus labialis (L. f.) Spreng. subsp. arabicus Verdc.

Clitoria ternatea L.

Crotalaria retusa $\mathrm{L}$.

Crotalaria spectabilis Roth

Piper borbonense (Miq.) C. DC.

Piper sylvestre Lam.

Peperomia portulacoides (Lam.) A. Dietr.

Peperomia tetraphylla (G. Forst.) Hook. et Arn.

Portulaca quadrifida L.

Flacourtia indica (Burm. f.) Merr.

Scolopia heterophylla (Lam.) Sleumer

Rubus alceifolius Poir.

Abrus precatorius $\mathrm{L}$.

Canna glauca L.

Canna indica L.

Elephantopus mollis Kunth

Psiadia anchusifolia (Poir.) Cordem.

Psiadia boivinii (Klatt) Rob.

Solanum mauritianum Scop. 
Thym marron

Thym marron

Vacoua marron

Vacoua marron rouge

Vanillier marron

Vava marron

Vigne marronne

Violette marron

Yapana marron

Zamal marron

Zamal marron

Zévi marron
Ambrosia tenuifolia Spreng.

Erica galioides Lam.

Pandanus montanus Bory

Pandanus purpurascens Thouars

Duranta erecta L.

Astelia hemichrysa Lam.

Rubus alceifolius Poir.

Centella asiatica (L.) Urb.

Justicia gendarussa Burm. f.

Conyza canadensis (L.) Cronquist

Conyza sumatrensis (Retz.) E. Walker

Poupartia borbonica J.F. Gmel.

\section{APPENDIX 2.}

List of Reunion creole vernacular plant names that have Malagasy origins. Source: Robert Chaudenson, Le Lexique du Parler Créole de la Réunion (Paris: H. Champion, 1974) pp. 496-534; updated and cross-checked with botanical databases CBNM (http://flore.cbnm.org) and Tropicos (http://www.tropicos.org/Project/MADA), accessed 15 Aug. 2014 and, when possible, creole spelling in Daniel Baggioni, Dictionnaire Créole Réunionnaise - Français. (Réunion, Azalées Éditions, 1990).

\begin{tabular}{|c|c|c|c|}
\hline Creole name & Meaning & Malagasy root & Meaning of Malagasy root \\
\hline Affouche & $\begin{array}{l}\text { different fig species (Ficus); note that } \\
\text { Ficus mauritana is figue marron }\end{array}$ & hafotra / hafotsa & Ficus; Malagasy root also refers to vines, ties \\
\hline Ambaville & $\begin{array}{l}\text { ericaceous bushes on the heights of the } \\
\text { island e.g. Hubertia spp. and Phylica } \\
\text { nitida }\end{array}$ & anjavily, anjavidy & ericaceous heath \\
\hline Ambrevade & $\begin{array}{l}\text { pigeon pea, Cajanus cajan (note also } \\
\text { that Crotalaria uncinella is 'abrevade } \\
\text { marron') }\end{array}$ & ambarivatry & Cajanus cajan, pigeon pea \\
\hline Andèze & Trema orientalis & andrarezina & Trema orientalis \\
\hline Bekabare & $\begin{array}{l}\text { identity unclear: Chaudenson says a } \\
\text { 'purslane-type plant' but then lists } \\
\text { Thrianthema camilli }\end{array}$ & & $\begin{array}{l}\text { Malagasy root means 'talkative'; they say if } \\
\text { you eat this plant you become talktative. }\end{array}$ \\
\hline
\end{tabular}




\begin{tabular}{|c|c|c|c|}
\hline Brèd mafane & $\begin{array}{l}\text { Acmella oleracea, common leafy green } \\
\text { with 'hot' flavour }\end{array}$ & mafana & hot (in Madagascar this plant is 'anamalaho') \\
\hline Cambarre & $\begin{array}{l}\text { variety of yam with purple interior } \\
\text { (Dioscorea alata) }\end{array}$ & kambara & Dioscorea alata, from Tanosy, Betsileo dialects. \\
\hline Faham & orchid Angraecum & fahamo & $\begin{array}{l}\text { Following Chaudenson, fahamo in Madagascar } \\
\text { apparently means Dichrostachys tennifolia, but } \\
\text { this is a leguminous herb }\end{array}$ \\
\hline $\begin{array}{l}\text { Fanjan, } \\
\text { Fangeon }\end{array}$ & $\begin{array}{l}\text { tree ferns Cyathea spp. and plant pots } \\
\text { created with their trunk }\end{array}$ & fantsaha, fanjana & Cyathea spp. \\
\hline Fataque & $\begin{array}{l}\text { grasses like Guinea grass (Urochloa } \\
\text { maxima), which Chaudenson cites as } \\
\text { being introduced in } 1700 \text { s }\end{array}$ & fatakana, fataka & Guinea grass, Urochloa maxima \\
\hline Foutac & $\begin{array}{l}\text { marsh plant Typha domingensis (and in } \\
\text { toponyms) T. domingensis now has } \\
\text { common name 'voune' (see below). }\end{array}$ & fotaka & mud \\
\hline Hoffe & $\begin{array}{l}\text { yam (Dioscorea alata) - less common } \\
\text { usage restricted to a particular variety }\end{array}$ & ovy & yam and more recently, potato \\
\hline Katafay & various trees of Melicope spp. & katrafay, katafa & Melicope \\
\hline Kivi, bwa de & $\begin{array}{l}\text { Turraea spp. (of which two species are } \\
\text { known as 'bois de café marron'); 'kivi' is } \\
\text { also synonym for 'marron' and found in } \\
\text { place names }\end{array}$ & kivy & etymology obscure \\
\hline Lingue & $\begin{array}{l}\text { A term in plant names; or specifically } \\
\text { Mussaenda spp. used in baths for skin } \\
\text { diseases. }\end{array}$ & laingo? ling? & etymology obscure \\
\hline Lingue pwa & $\begin{array}{l}\text { Piper borbonense, a vine that reminds of } \\
\text { the pepper tree, also known as 'poivrier } \\
\text { marron' }\end{array}$ & $\begin{array}{l}\text { laingo? ling? pwa } \\
\text { for poivrier }\end{array}$ & etymology obscure \\
\hline Longouze & $\begin{array}{l}\text { for several humid-zone plants in ginger } \\
\text { family, e.g. Hedychium spp. }\end{array}$ & longoza & $\begin{array}{l}\text { Aframomum angustifolium (also in the ginger } \\
\text { family) }\end{array}$ \\
\hline Mahafatiamboa & Cnestis glabra, poisonous for dogs & mahafaty amboa & $\begin{array}{l}\text { literally, 'kills dogs' (Cnestis glabra is native to } \\
\text { Madagascar) }\end{array}$ \\
\hline Mouffia & Raphia ruffia & mofia, rofia & Raphia ruffia \\
\hline Natte & $\begin{array}{l}\text { diverse trees, good for construction } \\
\text { including Mimusops balata, } \\
\text { Labourdonnaisia callophylloides, and } \\
\text { 'natte marron' (Sideroxylon spp.) }\end{array}$ & nato & $\begin{array}{l}\text { diverse trees with red wood, good for } \\
\text { construction, e.g. Mimusops }\end{array}$ \\
\hline
\end{tabular}




\begin{tabular}{|c|c|c|c|}
\hline Ravenal & $\begin{array}{l}\text { voyagers palm, Ravenala } \\
\text { madagasicarensis }\end{array}$ & ravinala & Ravenala madagasicarensis \\
\hline Ravintsara & $\begin{array}{l}\text { Cinnamomum camphora, camphor } \\
\text { laurel, also known as 'camphre'. }\end{array}$ & ravintsara & $\begin{array}{l}\text { Cinnamomum camphora, commercialized on } \\
\text { Madagascar as ravintsara oil. Not to be } \\
\text { confused with 'ravensara' (Ravensara spp., } \\
\text { also aromatic, not present in Reunion). }\end{array}$ \\
\hline Songe & taro (Colocasia esculenta) & saonjo & Colocasia esculenta \\
\hline Soulfas & Kalanchoe pinnata & soutou fafan [?] & etymology unclear \\
\hline $\begin{array}{l}\text { Tambour, bwa } \\
\text { de }\end{array}$ & tree, Tambourissa spp. & $\begin{array}{l}\text { ambora, } \\
\text { tamborosisa }\end{array}$ & $\begin{array}{l}\text { Tambourissa spp. (same genus, different } \\
\text { species) }\end{array}$ \\
\hline Tantan & $\begin{array}{l}\text { seed, plant and/or oil of castor (Ricinus } \\
\text { communis) }\end{array}$ & $\begin{array}{l}\text { tantan bafaa, } \\
\text { tanantanana }\end{array}$ & $\begin{array}{l}\text { oil plants like Jatropha curcas or Ricinus } \\
\text { communis }\end{array}$ \\
\hline Tetel, zerb de & herb that attracts bees & tantely & bees \\
\hline Vangasaille & Citrus reticulate, small, acid orange & voangisay & current word for orange is 'voasary' \\
\hline Vatangue & type of melon (no longer current word) & voatango & type of melon \\
\hline Vavangue & $\begin{array}{l}\text { fruiting tree, Vangueria } \\
\text { madagascariensis }\end{array}$ & voa/vangasay? & some doubt about etymology \\
\hline Voune & reed flowers (used to make mattresses) & vony & flower \\
\hline Vuem(b) & cowpea, Vigna unguiculata & voanemba & cowpea, Vigna unguiculata \\
\hline Zamal, Zamalle & $\begin{array}{l}\text { hemp (Cannabis), or 'zamal marron' } \\
\text { (Conyza spp.) }\end{array}$ & zamala & etymology obscure, probably Cannabis \\
\hline Zantak & hyacinth bean, Lablab purpureus & antaka & hyacinth bean, Lablab purpureus \\
\hline Zoumine & Cyperus spp. & ofimamy & Cyperus (according to Chaudenson) \\
\hline
\end{tabular}

